\title{
USING 3D BIM MODEL FOR THE VALUE-BASED LAND SHARE CALCULATIONS
}

\author{
N. Çelik Şimşek ${ }^{a^{*}}$, B. Uzun ${ }^{\mathrm{a}}$
}

${ }^{a}$ KTU, Department of Geomatics Engineering, 61080 Trabzon, Turkey-(nidacelik, buzun)@ktu.edu.tr

KEY WORDS: Land Share, BIM, Condominium Unit, Easement Right, Condominium Ownership

\begin{abstract}
:
According to the Turkish condominium ownership system, 3D physical buildings and its condominium units are registered to the condominium ownership books via 2D survey plans. Currently, 2D representations of the 3D physical objects, causes inaccurate and deficient implementations for the determination of the land shares. Condominium ownership and easement right are established with a clear indication of land shares (condominium ownership law, article no. 3). So, the land share of each condominium unit have to be determined including the value differences among the condominium units. However the main problem is that, land share has often been determined with area based over the project before construction of the building. The objective of this study is proposing a new approach in terms of value-based land share calculations of the condominium units that subject to condominium ownership. So, the current approaches and its failure that have taken into account in determining the land shares are examined. And factors that affect the values of the condominium units are determined according to the legal decisions. This study shows that 3D BIM models can provide important approaches for the valuation problems in the determination of the land shares.
\end{abstract}

\section{INTRODUCTION}

The subject of the immovable property is composed of (i) land, (ii) independent and permanent rights and (iii) condominium units that subject to condominium ownership in Turkey ${ }^{1}$. Existing land titling and property (cadastral) systems of these immovable properties have developed around the concept of a two dimensional mapping system. Attribute datas such as owner, parcel number, size, easements, condominium unit informations are registered to the title deed books by land registries.

There are two ways for registering of the condominium units to the land registry. One of them is, establishing of the condominium ownership after the completion of the construction. The other one is, establishing of the easement right in construction phase of the building in order to provide property right security. Current practices show that the easment right has been established in the subbasement level of the construction and registered to the condominium ownership books via 2D maps and plans (Fig. 1 and 2). Land share which is one of the most important and problematic subject in the condominium ownership system has been determined at that phase and stored land registry offices as an attachment of the architectural project.

This share, which is specific for each unit, is called the “ownership fraction' in some countries (Çağdaş, 2013). According to UNECE (2003) report; the formula is Ownership fraction = gross area of a unit / sum of gross area of all units for the calculation of this share.

Even if the definition has similar characteristics with Turkish case, its calculation method has some differences in Turkey.

\footnotetext{
${ }^{1}$ Official Gazette, Turkish Civil Code, law no:4721, acception date: 22/11/2001, publishing date: 8/12/2001, volume:41, article: 998
}

*Corresponding author
Land share related topics have been considered in accordance with the Law no: $634^{2}$ in Turkey and it is stated that;

- It is a co-ownership rate of the land parcel that allocated to the condominium unit,

- Land shares have to be determined with respect to location and dimension of the condominium units,

- It have to be determined by means of containing the value differentiation between the condominium units on the date of easement right/condominium ownership (Dörtgöz, 2000).

However, current practices, Deniz (2013) and Celik Simsek and Uzun (2017) show that 'equal rate based' or 'area based' land share calculations have comman usage in Turkey. But this kind of inadequate and unscientific appreciations lead to important immovable property conflicts, even years later.

The main problem is that, land share has often been determined with area based over the project before construction of the building and essential determinants couldn't be able to measured for the valuation process. The objective of this study is proposing a new approach in terms of value-based land share calculations of the condominium units that subject to condominium ownership. So, the current approaches and its failure that have taken into account in determining the land shares are examined. And factors that affect the values of the condominium units are determined according to the legal decisions/regulations. This study shows that 3D BIM models can provide important approaches for the valuation problems in the determination of the land shares.

\footnotetext{
2 Official Gazette, Condominium Ownership Law, law no:634, acception date: 23/6/1965, publishing date: 2/7/1965, volume:4, paper no:2932
} 


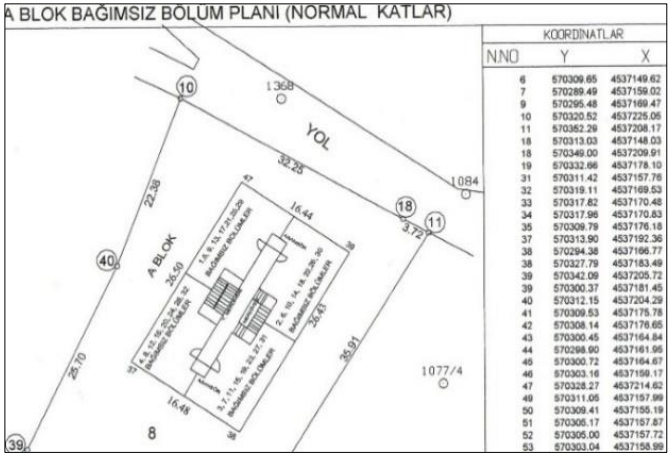

Figure 1. Condominium unit plan

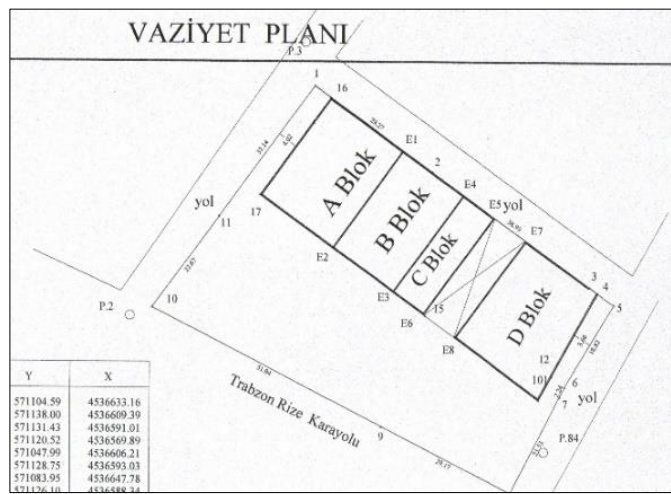

Figure 2. Layout plan

2. THE PROCESS OF THE DEVELOPMENT OF EASEMENT RIGHT FOR THE CONDOMINIUM UNITS

Establishing the easement right is the most basic step for the condominium units (3D physical objects) in the initial phase of the construction. In this phase, these units are registered and legal security is provided. There are some documents that has been used in that process. These are:

- Measurements of the condominium units, annexes and common spaces,

- Land shares of the condominium units,

- Number of the apartment, office, shop, cellar or warehouse which are in the same building,

- Building management plan,

- Architectural Project,

- Construction permit document,

- Layout plan,

- Condominium unit plan.

As seen in Fig. 3, there are some stages that have to be completed for the property right security from design to construction process of the building. In the first phase, civil engineers, architects and land surveyors prepare their projects (construction project, architectural project and setting out project). Layout and condominium unit plan are the part of these projects. Management plan is prepared by the land owners and agreement is arranged by title deed officers (Aybay and Sanal, 2010). After the Municipality's approval, a copy of the construction permit is given to the construction owner. In the second phase, when the construction comes to the sub-basement level, municipality check this level whether or not it is compatible with engineering projects. If everything is ok, construction owner gets original paper of the construction permit. In this phase landowner can start the process of establishing easement right with first phase documents and gets easement right title. In the third phase, after the completion of the construction, land owner can transform his/her property type from easement right to condominium ownership with additional documents.

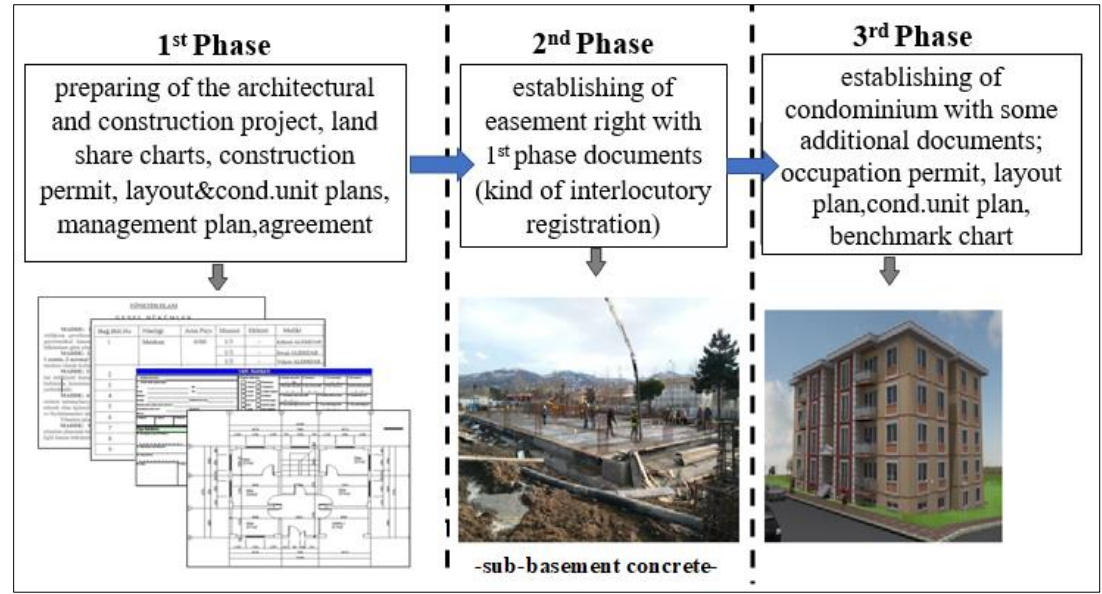

Figure 3. The process of establishing easement right and condominium ownership

\subsection{Land Share Determinations}

Both condominium ownership and easement right are based on the principal of establishing co-ownership on buildings and building parts with determining the land share. So, the land share of the each condominium unit should be determined by means of containing the value differentiation between the condominium units (Law no:634, article:3). Namely, valuation of the condominium unit is very important and play a crucial role in the entire process from construction to demolition of the building. Value-based land shares are important not only for title deed registrations but also for using rights in common places, restoration +maintenance+protection costs, executive decision-making in building, board of management meetings, in case of the expropriation of the whole building, management appointments, in the case of demolishing of the building, etc. 
The problem is that: architectural projects are prepared when the building is not physically on the land surface and projects prepared in design phase don't include valuation determinants and are not meaningful for cadastral/registry purposes. Besides, it is not easy to show their value on a 2D architectural project (in the digital cad format). However in the project phase land shares are determined over the project documents lacking of scientific determinats (addressed in Law no.634).

Current situation, area based and equal rate based methods have been used for the determination of the land share. As a result of that, there have been different land shares which are belonging to the same condominium unit (as seen in Table 1).

\begin{tabular}{|c|c|c|c|c|c|}
\hline $\begin{array}{l}\text { Condominium } \\
\text { number }\end{array}$ & $\begin{array}{ll}\text { Floor } & \text { Area } \\
\left(\mathbf{m}^{2}\right) & \end{array}$ & Unit value $(€)$ & $\begin{array}{l}\text { Land share } \\
\text { (based on area) }\end{array}$ & $\begin{array}{l}\text { Land share } \\
\text { (based on equal } \\
\text { rate) }\end{array}$ & $\begin{array}{l}\text { Land share } \\
\text { (based on value) }\end{array}$ \\
\hline 11 & 130 & 110.000 & $13 / 75(0,173)$ & $1 / 5(0,20)$ & $11 / 65(0,169)$ \\
\hline 12 & 130 & 110.000 & $13 / 75$ & $1 / 5$ & $11 / 65$ \\
\hline 13 & 150 & 130.000 & $15 / 75$ & $1 / 5$ & $13 / 65$ \\
\hline 14 & 160 & 140.000 & $16 / 75$ & $1 / 5$ & $14 / 65$ \\
\hline 15 & 180 & 160.000 & $18 / 75$ & $1 / 5$ & $16 / 65$ \\
\hline Total & 750 & 650.000 & 1 & 1 & 1 \\
\hline
\end{tabular}

Table 1. Determination of the land shares with different methods

So, this kind of incorrect and unscientific appreciations lead to important immovable property conflicts (especially in the context of condominium ownership). Whereas, land share should be determined value based (as stated in Law no. 634) and even if the building is not physically on the land surface, valuation should performed with the real measurements and datas from the 3D virtual building models (Celik Simsek and Uzun, 2017). This kind of a valuation system is not supported by the current land administration system. Moreover, according to Cete and Yomralioglu (2013); real estate valuation is one of the most problematic domains within the Turkish Land Administration System and real estate valuation system should be restructured in a holistic manner with land registry and cadastre components.

\subsection{Factors for the Accurate Land Share}

Factors that are essentail for the determination of the land share are handled in Condominium Ownership Law.

According to the Condominium Ownership Law (no:634, article:3);

- Land share should be determined by means of containing the value differentiation between the condominium units,

- Location and dimension of the condominium units are main determinants.

On the other hand, these factors are not limited with the relevant law. When we consider the Supreme Court decisions, we realise additional factors for the valuation of each unit (within the condominium ownership system). According to the Supreme Court Practices;

- Area, location, type of the unit,

- Floor number,

- Heating system,

- Fabrication cost per $\mathrm{m}^{2}$,

- Environmental features,

$\begin{array}{ll}\circ & \text { solar energy potential } \\ \circ & \text { wind } \\ \circ & \text { lighting } \\ \circ & \text { orientation, }\end{array}$

should be considered for such a valuation process (within the condominium ownership system).

\section{DETERMINATION of the LAND SHARE with BIM PROCESS}

There is a need for a new valuation process which analyzes above mentioned factors and defines land shares accurately. So, a new process that will create $3 \mathrm{D}$ geometric model of the condominium unit and at the same time running environmetal analysis should be accelerated. In the Architecture Engineering and Construction (AEC) world, BIM (Building Information Modeling) is a new way of holistically managing the information related to construction projects, from planning to design, construction and operations (CIC, 2013).

BIM has began to gain importance not only in the AEC sector but also in the geospatial world. So, geospatial information becomes a key component for the BIM usage in facility management. Moreover it is stated that; BIM has an important features that links to and makes use of some geospatial informations such as; property boundaries, zoning, soils data, elevation, jurisdictions, aerial images, land cover, land use, etc (OGC, 2017).

However, there are limited studies regarding with using Building Information Models (BIMs) for the management of immovable properties in Turkey. According to the Isikdag et al., (2015), the highly detailed BIMs provide opportunities for model-driven valuation for the new construction projects. In many countries a lot of properties are apartments and it is not easy to show their value on a 2D map (and adding a table to a complex building is not giving clear insights) and it could be an option to use a $3 \mathrm{D}$ building and/or cadastral models for this.

3D BIM models can provide important approaches for the valuation problems in the determination of the land share (Celik Simsek and Uzun, 2017). The model could be used for the following purposes (as illustrated in Fig. 4):

1. The building which is not actually built in the physical land surface can be generated as a $3 \mathrm{D}$ virtual building model.

2. The factors needed for the land share determination should be visualized and reported. 
Such as; floor area, level of floor, landscape, sunshine duration, construction cost, etc.

3. Determinants for the valuation of the condominium unit can be analysed on the model easily.

4. Differences of each condominium unit can be compared to the others become prominat (superior or missing features).

5. Condominium unit energy performance (solar, shadow, wind, etc.) can be considered with the support of environmental analysis function of the BIM softwares.

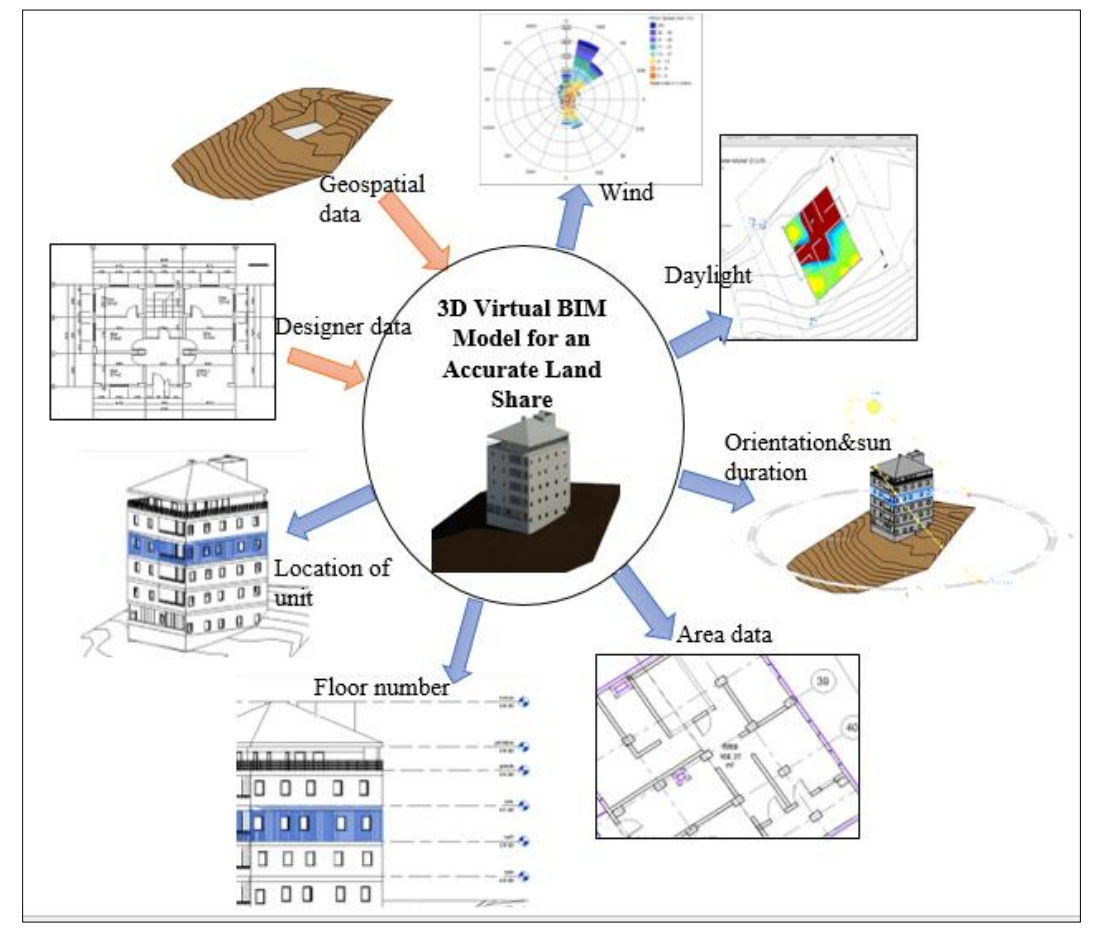

Figure 4. Land share factors defined with 3D BIM model

So, building elements with actual dimensions and details can be generated in the detailed design phase. 3D building serves as a real building and improves understanding of the expected end-result through visualization and virtual prototype. The decision-making process is accelerated and land share factors are determined and reported in a scientific manner (as stated in Condominium Ownership Law no.634).

\subsection{Case Study}

The building has been planning to construct, so the architectural project has prepared in format .dwg with the software AutoCAD and imported to the Autodesk Revit. Architectural and structural components were created in referencing with 2D plans. Material and thermal properties of glazing and opaque surfaces were defined according to the default settings of the programme (because of not having thermal insulation plans/reports). Building performance analysis regarding with sun and daylight levels were performed in Revit Architecture. According to Harputlugil (2014), performance simulations are very important for determining the building performance of the newly designed buildings and computer simulations are the most important tools for determining daylight illumination levels (BREEAM, 2015). Besides, the integration of Revit Architecture with market analysis tools, facilitates long and difficult analysis (Ayçam and Erbaş, 2017). So, climate based daylight metrics, such as Annual Sunlight Explosure (ASE) and Spatial Daylight Autonomy (sDA) (Wymelenberg and Mahić, 2016) were used for determining the annual energy performance of condominium units, in terms of its daylight and solar gain potential.

For the environmental calculations nearest weather station was selected (distance to the project: $3.4 \mathrm{~km}$, station number: 17626). According to the $\mathrm{sDA}_{300 / 50}$ metric results; floor areas of the condominium units in the building model did not achieve 300 lux for at least half of the analysis hours count as meeting the daylighting threshold. These values varied from 1 to 18 percent (as illustrated in Fig. 5). However, according to the LEED credit rating system at least $55 \%, 75 \%$, or $90 \%$ in regularly occupied areas where some daylight is important (LEED, 2017). In the project, floor areas of the condominium units were used instead of regularly occupied areas that's why the percentages of the illuminated areas had lower values (as seen in Table 2). However, the results are in desired level for determining the entire unit's daylight performance and making comparison. 


\begin{tabular}{|c|c|c|c|c|c|c|c|c|}
\hline $\begin{array}{c}\text { Cond. } \\
\text { unit } \\
\text { number }\end{array}$ & $\begin{array}{c}\text { Occupancy } \\
\text { type }\end{array}$ & $\begin{array}{l}\text { Construction } \\
\text { area of unit } \\
\qquad\left(\mathbf{m}^{2}\right)\end{array}$ & $\begin{array}{c}\text { Floor } \\
\text { number }\end{array}$ & $\begin{array}{l}\text { Heating } \\
\text { system }\end{array}$ & $\begin{array}{l}\text { Fabrica- } \\
\text { tion cost } \\
{\text { per } \mathbf{~ m}^{2}}^{\text {(tl) }}\end{array}$ & $\begin{array}{c}\text { Solar gain } \\
\text { ASE }_{1000 / 250} \\
(\%)\end{array}$ & $\begin{array}{c}\text { Daylight } \\
\text { SDA } 300 / 50 \% \\
(\%)\end{array}$ & $\begin{array}{l}\text { Orientat- } \\
\text { ion }\end{array}$ \\
\hline 1 & warehouse & 162,26 & $\begin{array}{l}-2 \\
\text { (under } \\
\text { ground } \\
\text { level) }\end{array}$ & no & 198 & 1 & 1 & South/East \\
\hline 2 & residential & 167,46 & $\begin{array}{l}\text {-1(under } \\
\text { ground } \\
\text { level) }\end{array}$ & $\begin{array}{l}\text { central } \\
\text { heating }\end{array}$ & 838 & 7 & 14 & South/East \\
\hline 3 & residential & 168,01 & $\begin{array}{c}0 \\
\text { (ground } \\
\text { level) }\end{array}$ & $\begin{array}{l}\text { central } \\
\text { heating }\end{array}$ & 838 & 6 & 16 & South/East \\
\hline 4 & residential & 166,9 & 1 & $\begin{array}{l}\text { central } \\
\text { heating }\end{array}$ & 838 & 6 & 17 & South/East \\
\hline 5 & residential & 166,27 & 2 & $\begin{array}{l}\text { central } \\
\text { heating }\end{array}$ & 838 & 6 & 18 & South/East \\
\hline
\end{tabular}

Table 2. Land share factors and their analysis results obtained from the BIM model

ASE measures the percentage of floor area that receives at least 1000 lux for at least 250 occupied hours per year (Sterner, 2014) and measures the presence of sunlight using annual hourly horizontal illuminance grids (Wymelenberg and Mahić, 2016). So the metric was used for determining the solar gains of each condominium unit. Analysis results indicated that (as seen in Table 2), the floor area of the each condominium unit exceeded the simulated value of 1000 lux for at least 250 hours per year. According to the results, condominium unit numbered one has the lowest percentage (1\%) and condominium unit numbered two has the highest percentage $(7 \%)$. It means that, one percent/seven percent of their floor area is exposed 1000lux illuminance for at least 250 hours of the year. Besides, spaces with ASE values exceeding 10 percent will likely result in visual discomfort. So, it clear that none of the condominium unit occupant has visual discomfort.

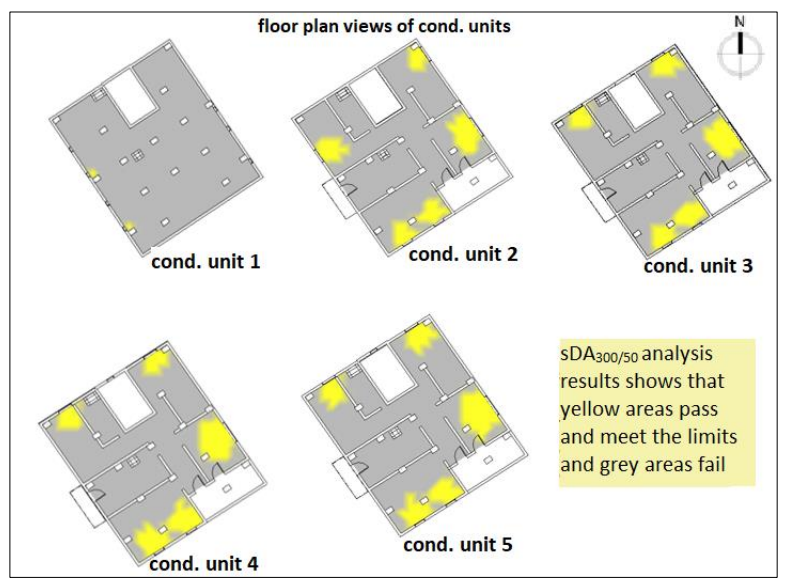

Figure 5. Visual sDA300/50\% results (building interior filled with daylight)
Other land share factors were determined easily from the building model such as building construction area, floor number, heating system, fabrication cost per $\mathrm{m}^{2}$ and orientation (northern winds availability). Even if these factors can be determined one by one from $2 \mathrm{D}$ plans or design schemas, the virtual BIM model gives an opportunity for the consideration of these factors on one dataset with more scientific manner.

The next step is using these distinct factors in the land share formulation. This process is not very easy because of the legal inefficiencies (there is no special valuation law in Turkey) and lack of legal codes regarding with the contribution rate/weight of these factors to the land shares. Nevertheless, factor weights have to be identified with individual studies. Weights that represent the influence quantity of the factors can be estimated with questionnaire study or stochastic analysis by using existing databases (Açlar and Çağdaş, 2002).

\section{CONCLUSION}

The most substantial feature for a condominium unit is being in the condominium ownership system. First step for that; establishing of the easement right and getting easement right title and second one is establishing of the condominium unit ownership and getting condominium ownership title. The most important component for both title deed is co-ownership share which defined as land share. Accurate and precise calculations have a crucial role from consrtuction to demolition and management of the building.

However, there are some missed points in terms of land share determinations in the current land management system. The necessity of value-based land share determination is emphasized but except that there are no detail explanations in Law no:634. However according to

\footnotetext{
${ }^{3}$ Obtained from "building approximate unit cost 2017" of Turkey Ministry of Environment and Urbanisation.
} 
the supreme court decisions there are too many factors that have to be considered in land share determination. In addition to, we are not able to take out these factors from $2 \mathrm{D}$ cad drawings.

Especially, building performance analysis (daylight availability and solar gains) has an important role in the land share process and using building models (with rich geometric and semantic information) is necessity to obtain these values accurately in design phase before the construction of building. The results obtained from daylight and solar gain simulations are functional in terms of determining variations between condominium units.

Land shares can be determined initial phase of the building (sub-basement level) and this phase has not appropriate information such a valuation process. So, we find out that BIM can be used for solving the problems regarding with the vertical landownership (condominium ownership). BIM can ensure accurate information from 3D virtual building model and can serve as an excellent decision making tool for condominium unit issues. Despite the fact that BIM world seems far away from the geospatial world, its functionality and detailed models containing geometric, topology and semantic information can provide usefull informations for the surveyors in the management of condominium units as 3D physical objects.

\section{REFERENCES}

Açlar, A. and Çağdaş, V., 2002. Taşınmaz (Gayrimenkul) Değerlemesi (in Turkish). TMMOB Harita ve Kadastro Mühendisleri Odası, Ankara, pp.347.

Aybay, A. and Sanal, N., 2010. Açıklamalı-İçtihatlı Kat Mülkiyeti Kanunu (in Turkish). Beta, İstanbul, pp.32

Ayçam, İ. and Erbaş, R., 2017. Yapı Bilgi Sistemlerinin (BIM) Ofis Binalarında Kullanım Alanları ve Potansiyeli (in Turkish). MMO Tesisat Mühendisliği Dergisi, 160, pp. 22-32.

BREEAM., 2015. International Refurbishment and Fit-out 2015 Scheme.

Celik Simsek, N. and Uzun, B., 2017. Trends and Expectations Towards to Three-Dimensional Property System in Turkey. In: FIG Working Week 2017, May 2017, Helsinki.

Cete, M. and Yomralioglu, T., 2013. Re-engineering of Turkish land administration. Survey Review, 45, 330, pp. 197-205.

Çağdaş, V., 2013. An Application Domain Extension to CityGML for immovable property taxation: A Turkish case study. International Journal of Applied Earth Observation and Geoinformation 21, pp. 545-555

CIC., 2013. Final Draft Report of the Roadmap for BIM Strategic Implementation in Hong Kong's Construction Industry.http://www.hkcic.org (4 Aug. 2017).

Deniz, D., 2013. Tapu Sicilinin Elektronik Ortamda Tutulmasi ve Tapu Kadastro Bilgi Sistemi (Takbis) Uygulamalar (in Turkish). Ankara Üniversitesi Fen
Bilimleri Enstitüsü, Taşınmaz Geliştirme Anabilim Dalı, Dönem Projesi.

Dörtgöz, G.Ö., 2000. Tapu İşlemleri (in Turkish). Takav Matbaacılık, Ankara, pp.38.

Harputlugil, G.U., 2014. Bina Enerji Performans1 Değerlendirme Araçları-Enerji Simülasyonu (in Turkish). Tesisat Mühendisliği, 144, pp.23-32.

Isikdag, U., Horhammer, M., Zlatanova, S., Kathmann, R., and Oosterom, P.V., 2015. Utilizing 3D Building and 3D Cadastre Geometries for Better Valuation of Existing Real Estate. In: FIG Working Week 2015, May 2015, Sofia.

LEED., 2017. Leed V4 For Building Design and Construction.

https://www.usgbc.org/sites/default/files/LEED\%20v4\%2 0BDC_07.8.17_current.pdf (28 Sep. 2017).

OGC., 2017. What is BIM About?

http://www.opengeospatial.org/ogc/marketstechnologies/ bim (4 Aug. 2017).

Sterner, C., 2014. Measuring Daylight: Dynamic Daylighting Metrics \& What They Mean for Designers. http://sefaira.com/resources/measuring-daylightdynamic-daylighting-metrics-what-they-mean-fordesigners/ (29 Sep. 2017).

UNECE., 2003. Guidelines on Condominium Ownership of Housing for Countries in Transition. United Nations Report, New York and Geneva.

Wymelenberg, K.V.D and Mahić, A., 2016. Adopted by the Illuminating Engineering Society, Spatial Daylight Autonomy and Annual Sunlight Exposure allow designers to quantify and compare the success of daylit spaces.

http://www.archlighting.com/technology/annualdaylighting-performance-metrics-explained_o (28 Sep.2017) 